\title{
Celebrating the 50th anniversary of bulletin of engineering geology and the environment
}

\author{
Resat Ulusay $^{1} \cdot$ Louis Wong ${ }^{2}$ \\ Published online: 18 August 2020 \\ (C) Springer-Verlag GmbH Germany, part of Springer Nature 2020
}

"Bulletin of the International Association of Engineering Geology" and "Bulletin of Engineering Geology and the Environment", as its previous and recent names, respectively, is the official journal of the International Association of Engineering Geology (IAEG) and created in 1970, six years after the establishment of IAEG. Starting as a simple artisanal publication, the Bulletin became a scientific reference among the most respected journals in the fields of engineering geology, the environment and other geoscience. This year, we are celebrating the 50th Anniversary of the Bulletin. It has been great honor and pleasure for the two Editors-in-Chief of the Bulletin to select 15 papers, with the assistance from the publisher, Samuel Goodchild for free access during September - October 2020. Three papers published in each decade with the highest number of citations are selected.

The IAEG was founded in 1964. At that time, few international societies had their own scientific journal. The first elected executive committee of IAEG decided at their second meeting at the UNESCO Palace, Paris, in May 1969 to create an official scientific journal of the IAEG, edited and published by the Association and named the "Bulletin of the International Association of Engineering Geology". As the official journal of IAEG, the Bulletin of the International Association of Engineering Geology was first published in 1970. The first Bulletin was distributed during the 1st IAEG Congress held in September 1970 in Paris, particularly

Resat Ulusay

resat@hacettepe.edu.tr

1 Department of Geological Engineering, Hacettepe University, 06800 Beytepe, Ankara, Turkey

2 Department of Earth Sciences, The University of Hong Kong, Hong Kong, Hong Kong with the personal efforts of Quido Záruba, the IAEG president, Jaroslav Pašek, Marcel Arnould and several other staff from the Paris School of Mines. In the first editorial in Bulletin No. 1 (presumably written by the secretary general, Marcel Arnould), it was indicated that the "Bulletin was not seen as being in competition with other engineering geological journals, rather, it is intended to be a common platform for communication where our members and all engineering geologists will find the news from the field of engineering geology". Marcel Arnould also wrote in the first editorial that the executive committee wanted the Bulletin to be a relatively modest affair with only two issues per year so that costs and, hence, subscription rates could be kept to a minimum.

The 1969 meeting in Paris also determined that the Bulletin would be bilingual, in the sense that authors could submit papers in either French or English. Each paper was to have an abstract and keywords in both French and English. This was in accordance with the founding philosophy of the IAEG, as stated in its statutes. The choice of two languages was a sign of the multicultural and multi-national nature of the Association. However, it is interesting to note further comments by Marcel Arnould in his 1972 General Assembly report that the executive committee left open the possibility of publishing abstracts in the other official languages of the IAEG - Russian, German, Italian and Spanish.

From 1970 to 1997, two issues were published per year. These were labelled as No. 1, No. 2 and so on. Consequently, by the end of 1997, 56 separate issues had been published in 28 years. From 1998, the system changed to four parts per year with a more conventional numbering system of volumes and parts. It was decided that the numerical sequence should be maintained so the four parts for 1998 became Issues 1 to 4 of Volume 57. Four issues had been published in each Volume until 2018. It was increased to 8 issues in 2019 (Volume 58), and 10 Issues are planned to be published in 2020 (Volume 59). 
At the IAEG Council meeting in June 1997 (Athens), it was agreed to change the name of the IAEG to the "International Association for Engineering Geology and the Environment". As a consequence, the Bulletin's name also changed to the "Bulletin of Engineering Geology and the Environment".

According to the IAEG amendments to the statutes, which came into effect in August 1974, and were published in Bulletin No. 10 in December 1974, the purpose of the Bulletin was: "To inform members and to promote publication for the worldwide dissemination of new engineering geological knowledge and techniques. The publication of the Bulletin is particularly devoted to this purpose". This confirmed the statement in the first editorial in Bulletin No. 1 that it was initially envisaged as a cross between a newsletter and a scientific journal. The IAEG statutes of 1992 stated that one of the aims of the IAEG was to, "...evaluate and disseminate the results of engineering geological activities on a worldwide basis by ... the publication of the scientific and technical achievements of members of the IAEG in the IAEG's own periodical and relevant news in the IAEG newsletter". Here there is a clear distinction between scientific publication and news.

Engineering geology is defined in the statutes of the IAEG as the science devoted to the investigation, study and solution of engineering and environmental problems which may arise as the result of the interaction between geology and the works or activities of man, as well as of the prediction of and development of measures for the prevention or remediation of geological hazards. The scope of the Bulletin is as follow, which can also be found in the following link: https://www.springer.com/ journal/10064/aims-and-scope

(a) the applications/implications of the geomorphology, structural geology, and hydrogeological conditions of geological formations;

(b) the characterization of the mineralogical, physicogeomechanical, chemical and hydraulic properties of all earth materials involved in construction, resource recovery and environmental change;

(c) the assessment of the mechanical and hydrological behavior of soil and rock masses;

(d) the prediction of changes to the above properties with time;

(e) the determination of the parameters to be considered in the stability analysis of engineering works and earth masses.

\section{List of papers arranged by decades}

Decade 2010-2019:

1) Corominas, J., van Westen, C., Frattini, P., Cascini, L., Malet, J.P., Fotopoulou, S., Catani, F., Van Den Eeckhaut, M., Mavrouli, O., Agliardi, F., Pitilakis, K., Winter, MG, Pastor, M., Ferlisi, S., Tofani, V., Hervas, J., Smith, J.T. (2014) Recommendations for the quantitative analysis of landslide risk. 73(2), pp.209-263.

2) Chapuis, R.P. (2012) Predicting the saturated hydraulic conductivity of soils: a review 71(3). pp.401-434.

3) Hajihassani, M., Armaghani, D.J., Marto, A. and Mohamad, E.T. (2015). Ground vibration prediction in quarry blasting through an artificial neural network optimized by imperialist competitive algorithm. 74(3), pp.873-886.

\section{Decade: 2000-2009}

4) Van Westen, C.J., Van Asch, T.W. and Soeters, R. (2006) Landslide hazard and risk zonation-why is it still so difficult? 65(2), pp.167-184.

5) Marinos, V., Marinos, P. and Hoek, E. (2005). The geological strength index: applications and limitations. 64(1), pp.55-65.

6) Marinos, P. and Hoek, E. (2001) Estimating the geotechnical properties of heterogeneous rock masses such as flysch. 60(2), pp.85-92.

\section{Decade: 1990-1999}

7) Aleotti, P. and Chowdhury, R. (1999) Landslide hazard assessment: summary review and new perspectives. 58(1), pp.21-44.

8) Hoek, E., Marinos, P. and Benissi, M. (1998) Applicability of the Geological Strength Index (GSI) classification for very weak and sheared rock masses. The case of the Athens Schist Formation, 57(2), pp.151-160.

9) Cruden, D.M. (1991) A simple definition of a landslide. 43(1), pp.27-29.

\section{Decade: 1980-1989}

10) Savage, W.Z. and Varnes, D.J. (1987) Mechanics of gravitational spreading of steep-sided ridges («sackung»). 35(1), pp.31-36. 
11) Matula, M. (1981) Rock and soil description and classification for engineering geological mapping report by the IAEG Commission on Engineering Geological Mapping. 24(1), pp.235-274.

12) Canuti, P., Focardi, P. and Garzonio, C.A. (1985) Correlation between rainfall and landslides [Corrélation entre chutes de pluie et glissements de terrain], 32(1), pp.49-54.

\section{Decade: 1970-1979}

13) Matula, M. (1979) Classification of rocks and soils for engineering geological mapping: part I: rock and soil materials. 19(1), pp.364-371.
14) Radbruch-Hall, D.H., Varnes, D.J. and Savage, W.Z. (1976) Gravitational spreading of steep-sided ridges ("sackung") in Western United States. 13(1), pp.23-35.

15) Hutchinson, N.N. (1977) Assessment of the effectiveness of corrective measures in relation to geological conditions and types of slope movement. 16(1), pp.131155 .

Reşat Ulusay, Louis N. Y. Wong

Editors-in-Chief

Bulletin of Engineering Geology and the Environment 